\title{
PEMANFAATAN IKAN GABUS (Channa striata) DAN TOMAT (Lypersion esculentum mill) SEBAGAI PENYEDAP RASA ALAMI
}

\author{
Rika Ramadhani Fitri \\ *Jurusan Gizi Poltekkes Kemenkes Riau
}

\begin{abstract}
ABSTRAK
Asam glutamat merupakan salah satu dari 20 asam amino yang ditemukan pada protein. Rasa gurih dapat berasal dari bahan alami, diantaranya adalah asam glutamat dari ikan gabus dan tomat. Saat ini di Provinsi Riau, ikan gabus adalah ikan lokal yang banyak digemari karena tingginya kandungan protein pada ikan ini dan banyaknya predator ikan gabus di sungai-sungai yang banyak terdapat di Riau khususnya. Ikan gabus mengandung air, rendah lemak, natrium, karbohidrat, rendah kalori, dan bebas kolesterol. Ikan gabus juga mengandung nutrisi penting termasuk kalsium, fosfor, besi, kalium, dan niasin. Tomat juga merupakan pangan lokal yang mengandung asam glutamate, selain itu tomat juga mengandung glukosa yang dapat dimanfaatkan sebagai pengganti gula. Adanya kandungan asam glutamat maka perlu dibuat penyedap rasa yang berasal dari ikan gabus dan tomat.

Percobaan ini dengan tiga perlakuan berbeda dari masing-masing sampel yaitu perlakuan A (tepung ikan gabus 40 gr dan tepung tomat 30 gr), perlakuan B (tepung ikan gabus $50 \mathrm{gr}$ dan tepung tomat $40 \mathrm{gr}$ ), perlakuan $\mathrm{C}$ tepung ikan gabus (60 gr dan tepung tomat $50 \mathrm{gr}$ ). Semua perlakuan ditambahkan masing-masing bawang merah 40 gr, bawang putih 30 gr, garam 30 gr dan lada putih 3 gr. Selanjutnya masing-masing perlakuan dilakukan uji organoleptik dengan parameter warna, aroma dan rasa.

Berdasarkan hasil uji organoleptik penyedap rasa, didapatkan hasil konsentrasi terbaik dari ketiga percobaan konsentrasidengan rata-rata warna (A) 4,7, (B) 4,8 dan (C) 4,7, rata-rata aroma (A) 4,6, (B) 4,7 dan (C) 4,8, rata-rata rasa (A) 4,5, (B) 3,7 dan (C) 4,6. Pada percobaan konsentrasi C tingkat kesukaan tepung ikan gabus $60 \mathrm{gr}$ dan tepung tomat 50 gr pada tingkat kesukaan rasa dan aroma. Sedangkan tingkat kesukaan warna pada perlakuan konsentrasi B 50 gr tepung ikan gabus dan 40 gr tepung tomat.
\end{abstract}

Kata Kunci : Penyedap Rasa Alami, Ikan Gabus, Tomat, uji organoleptik 


\section{PENDAHULUAN}

Ikan gabus merupakan salah satu jenis ikan air tawar yang berasal dari daerah tropis. Ikan gabus ini banyak ditemukan di perairan umum, yang dapat tumbuh dan berkembang dimuara - muara sungai dan dapat juga berkembangbiak di perairan kotor rendah kadar oksigen bahkan juga tahan terhadap kekurangan air. Ikan ini biasanya memiliki ciri - ciri fisik umum yaitu memiliki bentuk tubuh memanjang dan bagian belakang berbentuk pipih (compressed).

Berdasarkan buku TKPI (Tabel Komposisi Pangan Indonesia) ikan gabus per 100 gram bagian yang dapat dimakan dengan kandungan air 79,6 gr, energi 80 kkal, protein $16,2 \mathrm{gr}$, lemak $0,5 \mathrm{gr}$, karbohidrat 2,6 gr, abu 1,1 gr, kalsium 170 $\mathrm{mg}$, fosfor $139 \mathrm{mg}$, besi $0,1 \mathrm{mg}$, natrium 65 $\mathrm{mg}$, kalium $254 \mathrm{mg}$, tembaga $0,3 \mathrm{mg}$, seng 0,4 dan niasin $0,2 \mathrm{mg}$.

Asam amino yang terkandung dalam albumin ikan gabus yang paling tinggi komposisinya adalah asam glutamate yaitu sebesar 30,93 gram yang kedua adalah lisine 17,02 g dan asam aspartat yaitu sebesar 17,02 gram. Asam amino yang terendah adalah sistein yaitu sebesar 0,16 gram. Lisin merupakan 1 dari 10 asam amino essensial yang tidak dapat disentesis dalam jumlah cukup dalam tubuh sehingga harus diperoleh dalam asupan makanan sedangkan asam glutamat, asam aspartat dan sistein merupakan asam amino non essensial (Guyton, 2008).

Dalam buah tomat banyak terkandung zat-zat yang berguna bagi tubuh manusia. Zat-zat yang terkandung di dalamnya antara lain karbohidrat, protein, lemak, vitamin B1, B2, B3, dan C, kalsium, fosfor, besi, natrium, kalium, serat, dan air. Tomat mengandung karoten yang berfungsi sebagai pembentuk provitamin A dan Lycoppen yang mampu mencegah kanker. Buah Tomat Masak adalah bahan makanan nabati yang biasa dikonsumsi oleh masyarakat Indonesia. Buah Tomat Masak mengandung energi sebesar 20 kilokalori, protein 1 gram, karbohidrat 4,2 gram, lemak 0,3 gram, kalsium 5 miligram, fosfor 27 miligram, dan zat besi 0 miligram. Selain itu di dalam Buah Tomat Masak juga terkandung vitamin A sebanyak $1500 \mathrm{IU}$, vitamin B1 0,06 miligram dan vitamin C 40 miligram. Hasil tersebut didapat dari melakukan penelitian terhadap 100 gram Buah Tomat Masak, dengan jumlah yang dapat dimakan sebanyak $95 \%$.

Bahan penyedap alami yang sering digunakan untuk menimbulkan rasa gurih pada makanan antara lain santan kelapa, ikan, keju, terasi, tomat, susu sapi, dan kacang-kacangan. Selain itu, bahan penyedap lainnya yang biasa digunakan sebagai bumbu masakan, antara lain lengkuas, ketumbar, cabai, kayu manis, dan pala. Tujuan ditambahkannya penyedap adalah meningkatkan cita rasa makanan, mengembalikan cita rasa makanan yang mungkin hilang saat pemprosesan dan memberi cita rasa tertentu pada makanan (Sediaoetomo, 1985). 
METODE PENELITIAN

Tabel 1. Tahapan Penelitian

\begin{tabular}{|c|}
\hline $\begin{array}{c}\text { Persiapan Bahan Penelitian dan Pembuatan } \\
\text { Tepung }\end{array}$ \\
\hline $\begin{array}{l}\text { Pembuatan Produk } \\
\text { Variasi jumlah tepung ikan gabus ( } 40 \text { gr, } 50 \\
\text { gr dan } 60 \mathrm{gr} \text { ) serta tepung tomat ( } 30 \mathrm{gr}, 40 \\
\text { gr dan } 50 \mathrm{gr} \text { ) dengan penambahan garam, } \\
\text { bawang merah, bawang putih dan lada }\end{array}$ \\
\hline $\begin{array}{c}\text { Uji Organoleptik: } \\
\text { Warna, Aroma, dan Rasa Penyedap rasa } \\
\text { alami }\end{array}$ \\
\hline Analisa Data \\
\hline
\end{tabular}

Pada pembuatan produk penyedap rasa alami langkah awal yang harus dilakukan adalah pembuatan tepung ikan gabus dan tepung tomat yang selanjutnya akan ditambahkan formulasi bawang merah, bawang putih, lada dan garam. Hasil produk ini adalah serbuk penyedap rasa alami dengan konsentrasi tepung ikan gabus $60 \mathrm{gr}$, 50 gr dan 40 gr. Sedangkan konsentrasi tepung tomat $50 \mathrm{gr}, 40 \mathrm{gr}$ dan 30 gr seperti pada table berikut:

\begin{tabular}{|l|c|c|c|}
\hline \multicolumn{1}{|c|}{ Bahan } & A & B & C \\
\hline $\begin{array}{l}\text { Tepung Ikan } \\
\text { Gabus }\end{array}$ & $40 \mathrm{gr}$ & $50 \mathrm{gr}$ & $60 \mathrm{gr}$ \\
\hline Serbuk Tomat & $30 \mathrm{gr}$ & $40 \mathrm{gr}$ & $50 \mathrm{gr}$ \\
\hline Garam & $30 \mathrm{gr}$ & $30 \mathrm{gr}$ & $30 \mathrm{gr}$ \\
\hline Bawang Putih & $30 \mathrm{gr}$ & $30 \mathrm{gr}$ & $30 \mathrm{gr}$ \\
\hline $\begin{array}{l}\text { Bawang } \\
\text { Merah }\end{array}$ & $40 \mathrm{gr}$ & $40 \mathrm{gr}$ & $40 \mathrm{gr}$ \\
\hline Lada Putih & $3 \mathrm{gr}$ & $3 \mathrm{gr}$ & $3 \mathrm{gr}$ \\
\hline
\end{tabular}

Tabel 2. Formulasi Bahan

\section{HASIL PENELITIAN}

Melihat kandungan proksimat pada ikan gabus dan tomat sangat memenuhi sebagai makanan sehat, karena mengandung protein, karbohidrat, vitamin, rendah lemak dan kaya mineral yang cocok sebagai pengganti penyedap rasa alami itu sendiri dari bahan pangan yang terkandung nutrisi tersebut. Kandungan asam glutamate pada ikan gabus, merupakan bahan dasar sebagai penyedap rasa pada makanan olahan karena menimbulkan rasa gurih. Berdasarkan hasil uji organoleptik penyedap rasa ikan gabus (Channa striata)dan Tomat (Lypersion esculentum mill)terhadap 30 panelis yakni mahasiswa jurusan Gizi Poltekkes Kemenkes Riau tingkat dua dan tingkat tiga disimpulkan sudah memiliki pengetahuan terhadap uji organoleptik dan kemampuan dalam hal memasak dan mencicip.

Uji daya terima konsumen terhadap penyedap rasa alami dilakukan untuk mengetahui tingkat kesukaan konsumen terhadap penyedap rasa alamimeliputi warna, aroma dan rasa. Hasil uji daya terima dari ambil dari panelis sebanyak 30 orang. Daya terima rasapenyedap rasa alami oleh konsumen kemudian di rangking dan hasil rangking yang paling disukai adalah ikan dengan penambahan tepung ikan gabus 60 $\%$ dan tepung tomat $50 \%$, sedangkan daya terima penyedap rasa alami yang kurang disukai konsumen adalah penyedap rasa alamidengan penambahan tepung ikan gabus $50 \%$ dan tepung tomat $40 \%$. Pada uji 
organoleptik didapat hasil nilai rata-rata terhadap warna, aroma dan rasa pada tabel 5.1 berikut:

Tabel 5.1 Nilai rata-rata hasil uji organoleptik warna, aroma dan rasa

\begin{tabular}{llll}
\hline Sampel & \multicolumn{3}{c}{ Parameter yang diuji } \\
& Warna & Aroma & Rasa \\
\hline A & $4,73^{\mathrm{a}}$ & $4,63^{\mathrm{a}}$ & $4,53^{\mathrm{b}}$ \\
B & $4,83^{\mathrm{a}}$ & $4,77^{\mathrm{a}}$ & $3,73^{\mathrm{a}}$ \\
$\mathrm{C}$ & $4,77^{\mathrm{a}}$ & $4,83^{\mathrm{a}}$ & $4,57^{\mathrm{b}}$ \\
\hline
\end{tabular}

Ket:

1. Angka yang semakin tinggi berarti semakin disukai.

2. Angka yang diikuti dengan huruf yang sama pada kolom yang sama menunjukkan ada beda yang nyata dengan uji duncen $\alpha$ : 0,05\%.

\section{PEMBAHASAN}

Uji organoleptik ini dengan tiga perlakuan berbeda antara jumlah penambahan tepung ikan gabus dan tepung tomat. Perbandingan ini dibuat bertujuan kepada panelis untuk menentukan tingkat kesukaan pada perlakuan yang disukai masing-masing. Sebagai penilaian diberikan range tingkat kesukaan dari point keenam sampai point kesatu. Dari ketiga perbandingan perlakuan dapat diketahui grafik tingkat kesukaan masing-masing perlakuan warna, aroma dan rasa.

\section{Warna}

Warna merupakan salah satu parameter selain cita rasa, tekstur dan nilai nutrisi yang menentukan persepsi konsumen terhadap suatu bahan pangan. Preferensi konsumen sering kali ditentukan berdasarkan penampakan luar suatu produk pangan. Warna pangan yang cerah memberikan daya tarik yang lebih terhadap konsumen. Warna pada produk pangan memiliki beberapa fungsi antara lain: sebagai indikator kematangan, terutama untuk produk pangan segar seperti buah- buahan, sebagai indikator kesegaran misalnya pada produk sayuran dan daging dan sebagai indikator kesempurnaan proses pengolahan pangan misalnya pada proses penggorengan, timbulnya warna coklat sering kali dijadikan sebagai indikator akhir kematangan produk pangan (Fajriyati, 2012). Hasil uji organoleptik warna pada penyedap rasa alami ikan gabus dan tomat dengan jumlah 142 sampai dengan 145 dari nilai sempurna 180. Grafik hasil uji organoletik warna pada penyedap rasa alami dapat dilihat pada Gambar 5.1 berikut:

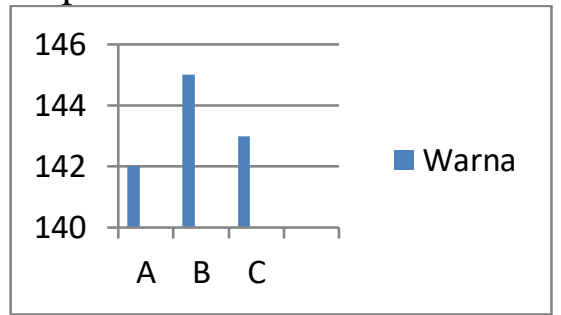

\section{Gambar 5.1 Grafik Hasil Uji Kesukaan terhadap Warna}

Nilai organoleptik warna pada penyedap rasa dengan formulasi bahan yang berbeda tidak memberikan nilai yang berbeda. Penyedap rasa yang dihasilkan memiliki nilai yang hampir sama. Warna pada serbuk cenderung gelap dikarenakan bahan yang digunakan yaitu tepung ikan gabus dan tepung tomat yang berwarna kecoklatan. Warna coklat pada tepung disebabkan karena terjadinya reaksi pencoklatan enzimatik ketika pengolahan menjadi tepung yang disebabkan oleh aktivitas oksidase seperti fenolase atau polifenolase dan katekolase yang akan mengkatalisis reaksi oksidasi senyawa fenol menjadi keton. Warna ini selain karena reaksi pencoklataan secara enzimatis juga disebabkan karena reaksi pencoklatan secara nonenzimatik yaitu reaksi Maillard selama pemanggangan. Reaksi Maillard adalah reaksi - reaksi antara karbohidrat, khususnya gula pereduksi dengan gugus amina primer (Winarno, 2004).

Warna pada setiap perlakuan serbuk penyedap rasa cenderung sama yaitu coklat 
ke orange, hal ini karena reaksi pencoklatan pada pemanasaran dan warna orange dari tomat, namun masih dapat diterima oleh panelis dan digolongkan dalam kategori suka dan netral. Warna pada penyedap Pada perlakuan B warna serbuk penyedap rasa yang paling digemari.

Warna coklat pada pembuatan tepung ikan dapat dicegah dengan perendaman air jeruk nipis \pm 6 jam karena penurunan $\mathrm{pH}$ mengakibatkan warna tepung ikan menjadi lebih terang, selain itu dalam larutan jeruk nipis terdapat alpha hydroxy acid (AHA) yang berfungsi untuk memberikan efek pencerahan. Warna coklat akibat reaksi fenolase pada tepung ikan gabus dapat dicegah dengan cara meminimalkan kontak dengan udara yaitu dengan cara perendaman dengan air (atau larutan garam 1\%) dan atau menginaktifkan enzim dalam proses blansir (Maulida, 2005).

\section{Aroma}

Aroma pada makanan banyak menentukan kualitas produk dari makanan. Aroma makanan dapat dikenali bila berbentuk uap, dan molekul - molekul komponen aroma tersebut harus menyentuh silia sel olfaktori. Aroma pada tepung ikan gabus dan tomat cenderung beraroma amis. Aroma amis pada disebabkan oleh tepung ikan gabus yang digunakan. Aroma amis pada ikan disebabkan oleh komponen nitrogen yaitu guanidin, trimetil amin oksida (TMAO), dan turunan imidazole (Maulida, 2005).

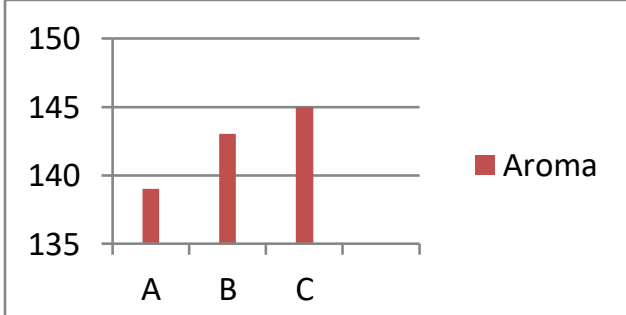

\section{Gambar 5.2 Grafik Hasil Uji Kesukaan terhadap Aroma}

Aroma pada serbuk penyedap rasa alami berkisar 139 sampai dengan 145dari nilai sempurna 180, tidak berpengaruh terhadap tingkat penerimaan oleh panelis. Penyedap rasa alami mempunyai tingkat penerimaan yang sama terhadap aroma. Aroma pada semua perlakuan hampir sama yaitu harum khas rempah namun ada aroma amis dari formulasi tepung ikan gabus dan aroma khas gula dari tomat akibat senyawa volatile gula pereduksi.

Aroma amis pada ikan dapat dikurangi dengan perendaman pada air jerik nipis selama \pm 6 jam, hal ini disebabkan karena air jeruk nipis mengandung minyak atsiri Limonen yang dapat menghilangkan bau amis pada ikan tersebut. Aroma dari tepung tomat juga dikarenakan senyawa volatile yang mempunyai bau khas (Maulida, 2005).

Namun jika dibandingkan dengan ketiga perlakuan, aroma yang paling banyak digemari adalah perlakuan $\mathrm{C}$ yaitu $60 \mathrm{gr}$ tepung ikan gabus dan 50 gr tepung tomat.

\section{Rasa}

Rasa adalah salah satu aspek yang penting dari suatu produk makanan. Rasa juga dapat menentukkan apakah produk makanan tersebut dapat diterima atau tidak oleh konsumen. Rasa makanan dapat dikenali oleh papila yang terdapat pada lidah. Rasa pada makanan terdiri dari rasa asin, manis, pahit, asam. Rasa pada makanan dipengaruhi oleh beberapa faktor yaitu senyawa kimia, suhu, konsentrasi dan interaksi dengan komponen rasa lain (Winarno, 2004).

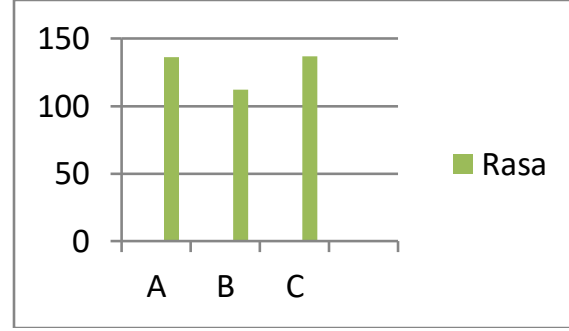

\section{Gambar 5.2 Grafik Hasil Uji Kesukaan terhadap Rasa}

Uji statistik diketahui bahwa ada perbedaan pengaruh penambahan tepung 
ikan gabus dan tepung tomat terhadap tingkat penerimaan rasa berkisar 112 sampai dengan 137 dari nilai sempurna 180. Tingkat penerimaan pada perlakuan $\mathrm{C}$ dan A paling digemari, sedangkan pada perlakuan B tingkat penerimaan rasa kurang digemari. Rasa pada penyedap rasa tergolong gurih, asin, manis menjadi satu karena adanya komposisi gula dari tomat, gurih akibat asam glutamate pada ikan gabus yaitu protein yang cukup besar, garam, lada dalam pembuatan penyedap rasa alami.Rasa khas pada buah tomat terutama disebabkan oleh gula yang terlarut, asam organik dan senyawa volatile yang terkandung mempengaruhi tingkat kesukaan rasa panelis.

Keragaman budaya Indonesia memberikan keragaman peninggalan budaya pemanfaatan herbal dan rempah-rempah. Selanjutnya, herbal dan rempah-rempah mulai banyak digunakan sebagai penyedap (flavoring) untuk makanan dan minuman. Dengan berjalannya waktu, bahan alami herbal dan rempah-rempah bukan saja digunakan untuk meningkatkan cita rasa, namun juga digunakan sebagai bahan untuk menunda atau mencegah ketengikan dan kerusakan makanan. Rempah-rempah dapat mempengaruhi aroma, warna dan rasa makanan dan kadang-kadang dapat menutupi aroma yang tidak dikehendaki. Senyawa volatil memberi aroma dan oleoresin mempengaruhi rasa makanan. Pengetahuan ini mendorong penggunaan rempah-rempah diberbagai macam pengolahan makanan. Penyedap rasa alami diharapkan menjadi "trend" dimasa yang akan datang, karena selain sehat juga dapat meningkatkan daya tahan tubuh. Pada penyedap rasa ikan gabus dan tomat telah ditambahkan rempah yang telah diketahui khasiat dan manfaatnya serta mempunyai aroma sedap seperti bawang merah (Allium cepa), bawang putih (Allium sativum), dan lada putih (Piper nigrum) (Widyastuti, 2015).

Pada hakikatnya, pemberian MSG didalam makanan tidak dilarang, namun hal ini perlu diminimalisir karena dampaknya yang kurang baik di dalam tubuh manusia terutama apabila penggunaan yang melebihi dosis dan terus-menerus. Banyak makanan yang dapat dikonsumsi sehari-hari yang mengandung asam glutamate sehingga mempunyai rasa gurih tergantung dari jenisnya. Glutamat yang terjadi secara alami dapat ditemukan dalam daging dan sayuran, sedangkan inosinate terutama berasal dari daging dan guanylate dari sayuran. Dengan demikian, rasa umami (gurih dan lezat) adalah umum untuk makanan yang mengandung L-glutamat dengan kadar tinggi terutama pada ikan, kerang, daging, daging asap, serta sayuran (seperti jamur, tomat, sawi putih, bayam, seledri dan lainnya atau produk fermentasi seperti keju, petis, kecap dan lainnya (Widyastuti, 2015).

\section{KESIMPULAN}

1. Pengaruh pemanfaatan ikan gabus dan tomat sebagai penyedap rasa alami terhadap tingkat kesukaan warna pada perlakuan B yaitu konsentrasi tepung ikan gabus $50 \mathrm{gr}$ dan tepung tomat 40 gr dengan hasil warna orange kecoklatan.

2. Pengaruh pemanfaatan ikan gabus dan tomat sebagai penyedap rasa alami terhadap tingkat kesukaan aroma pada perlakuan $\mathrm{C}$ yaitu konsentrasi tepung ikan gabus $60 \mathrm{gr}$ dan tepung tomat 50 gr dengan hasil aroma khas yang lebih pekat.

3. Pengaruh pemanfaatan ikan gabus dan tomat sebagai penyedap rasa alami terhadap tingkat kesukaan warna pada perlakuan $\mathrm{C}$ (tepung ikan gabus 60 gr dan tepung tomat 50 gr) dan perlakuan A (tepung ikan gabus 400 gr dan tepung tomat 30 gr), 
namun dari segi ekonomis perlakuan A lebih terjangkau dan diminati dengan hasil rasa gurih, khas dan pekat dari produk.

\section{DAFTAR PUSTAKA}

Achmad Djaeni Sediaoetama. 1985. Ilmu

Gizi. Jakarta: Dian Rakyat.110-139.

Bernardinus T. Wahyu Wiryanta. Bertanam Tomat. 2002. Jakarta:Agromedi.Pustaka.H laman

6.

Guyton, A.C., dan Hall, J.E. 2008. Buku

Ajar Fisiologi Kedokteran. Edisi 11.Jakarta:EGC

Jones, T. A., Bury, S. D., Adkins Muir, D. L., Luke, L. M., Allred, R. P. , \& Sakata,J. T.2008. Importance of behav- ioral manipulationsan measures in rat modelsof brain damage and brain repair. ILAR Journal,44, $\quad 144-152$.

Machin, Ahmad, 2012. Biosantifika Potensi Hidrolisat Tempe sebagai Penyedap Rasa.SMA Negeri 1 Dempet. Jawa

Tengah.

Mahmud dkk., 2008. Tabel Komposisi

Pangan Indonesia. Jakarta : PT Elex Media Komputindo. Manangka,

Christoper Apri, dkk,.Pemanfaatan Tumbuhan sebagai Penyedap Rasa

Alami oleh Masyarakat Suku Dayak Kanayatn Desa

Sebatih.Universitas

Tanjungpura.Pontianak.

Maulida, Nurul. Pemanfaatan Tepung Tulang Ikan Madidihang Sebagai Suplemen dalam Pembuatan Biskuit [skripsi]. Fakultas Perikanan dan Ilmu Kelautan. Institut Pertanian Bogor. Bogor; 2005.
Muchtadi, T. R. \& Sugiyono. 1992. Ilmu

Pengetahuan Bahan Pangan. Bogor. Institut Pertanian Bogor.

Setiawati, S. 2008. Proses Pembelajaran

Dalam Pendidikan Kesehatan. Jakarta

: Trans Info Media.

Sundari, I, dkk. 2014. Pengaruh Penggunaan Bioaktivator Em4

Dan Penambahan Tepung Ikan Terhadap Spesifikasi Pupuk Organik Cair Rumput Laut Gracilaria Sp. Semarang: Jurnal Pengolahan dan Bioteknologi Hasil Perikanan.

Octaviyanti, Nadhia.2017. Mutu Kimiawi dan Mutu Organoleptik Kaldu Ayam Bubuk dengan penambahan Sari Bayam Hijau. Jurnal Teknologi Pangan.Vol.6.2.2017.

Widyastuti, N, dkk. 2015. Potensi Beberapa Jamur Basidiomycota Sebagai Bumbu Penyedap Alternatif Masa Depan. Banten: Jurnal Teknologi Biosintesa . Winarno F.G. 2004. Kimia Pangan dan Gizi.PT

Gramedia Pustaka.Utama.Jakarta.

Winarno F.G. 1990. Teknologi Fermentasi Proyek Pengembangan Pusat Fasilitasi bersama antar Universitas, PAU Pangan dan Gizi, UGM, Yogyakarta. 